\title{
Domateste Rhizoctonia solani ve Pythium deliense Tarafindan neden olunan Çökerten Hastalığının Biyolojik Mücadelesinde Farklı İnokulasyon Yöntemlerinin Etkinlikliklerinin Belirlenmesi ${ }^{1}$
}

\author{
Ayșe AŞKIN², Filiz ÜNAL ${ }^{2}$, Ercan KOCA ${ }^{2}$ \\ Determination of the Efficiency of Different Inoculation Methods for the \\ Biological Control of Tomato Damping-Off Caused by Rhizoctonia solani and \\ Pythium deliense
}

\begin{abstract}
Rhizobacterial isolates can be applied with different inoculation methods in studies of the biological control of plant disease agents. These methods include mixing the suspension of bacteria with autoclaved soil, dipping the roots of seedlings in a bacterial suspension during transplanting or coating seeds with a bacterial suspension before sowing. In this study, the effect of the biocontrol agent Pseudomonads putida 10fp, which was isolated from a tomato rhizosphere, was evaluated for its biocontrol potential against the tomato damping-off disease agents, Rhizoctonia solani and Pythium delicense, under in vivo conditions by using different inoculation methods (application dose and format). There was no difference in the disease incidence recorded for treatments in which P. putida $\mathrm{fp} 10$ was applied into the soil, seed or seed+soil and at different doses $\left(10^{8}, 10^{9}\right.$ and $\left.10^{11} \mathrm{cfu} / \mathrm{ml}\right)$ against damping-off. However, plant growth was affected at different levels of inoculation. The best growth of both tomato varieties was observed after the application of a bacterial suspension into the soil at $10^{8} \mathrm{cfu} / \mathrm{ml}$.
\end{abstract}

Keywords: Biological control, fluorescent Pseudomonads, Rhizoctonia solani, Pythium deliense, inoculation methods.

Öz: Rizosfer bakterileri ile bitki hastalık etmenlerinin biyolojik mücadelesi üzerine yapılan çalışmalarda kök bakteri izolatları farklı şekillerde uygulanabilmektedirler. Bu metodlar bakteri süspansiyonunun steril toprağa karıştırılması, şaşırtma esnasında fide köklerinin bakteri süspansiyonuna daldırılması veya ekimden önce yüksek sayıdaki bakteri ile tohumların kaplanmasını içermektedir. Bu çalışmada, domates rizosferinden izole edilen ve çökerten zararına yol açan Rhizoctonia solani ve Pythium deliense' ye karşı in vivo koşullarda etkili olduğu daha önceki çalışmalarla belirlenen Pseudomonas putida 10fp

${ }^{1}$ Bu çalışma, 16-18 Mayıs 2017 tarihinde Tekirdağ'da düzenlenen II. Uluslararası Balkan Kongresi'nde poster olarak sunulmuş ve özet olarak basılmıştır. Doktora tezinin bir bölümüdür.

${ }^{2}$ Zirai Mücadele Merkez Araştırma Enstitüsü - ANKARA

Sorumlu yazar (Corresponding author) e-mail: ayșe.askin@tarim.gov.tr

Alınış (Recieved): 29.09.2017 Kabul ediliş (Accepted): 09.03.2017 
$\underline{\text { Domateste Cëkerten Hastalığının Biyolojik Mücadelesinde Farklı İnokulasyon Yöntemleri }}$

izolatının, bu patojenlere karşı farklı uygulama dozu ve uygulama biçimindeki etkileri araştırılmıştır. Sonuçlar göstermiştir ki P. putida fp10' nun çökertene karşı tohum, toprak ya da tohum+toprak şeklinde $10^{8}, 10^{9}$ and $10^{11} \mathrm{cfu} / \mathrm{ml}$ gibi farklı konsantrasyon uygulanmaları hastalık şiddetinde farklılık yaratmazken, bitki gelişimini farklı şekillerde etkilemiştir. Her iki domates çeşidinde de en iyi fide gelişimi $10^{8} \mathrm{cfu} / \mathrm{ml}$ konsantrasyonunda bakteri süspansiyonunun topraklara yapılan uygulama şeklinde görülmüştür.

Anahtar kelimeler: Biyolojik mücadele, floresan Pseudomonas, Rhizoctonia solani, Pythium deliense, inokulasyon metodları

\section{Giriş}

Çökerten hastalığı, domates yetiştiriciliğinde erken dönemde sorun olan önemli hastalıklardan birisidir. Çimlenen tohumlarda ve genç fidelerde ölümlere yol açar. Fidelik koşulları uygun olduğu takdirde hastalık, fidelerin tamamen tahrip olmasına neden olabilmektedir. Çökertenin oluşmasında değişik toprak fungusları etkili olur. En fazla sorumlu olan fungus Pythium spp. dir (Stephens et al. 1982). Bu fungus yanında Rhizoctonia solani, Fusarium spp. ve Phytophthora spp. de çökerten oluşumunda etkili olan diğer toprak patojenleridir (Karahan 1965, Stephens et al. 1982, Walker 1952). Domates fideliklerinde çökerten hastalığı ülkemizde de oldukça önemlidir. Hastalığın mücadelesinde kullanılmak üzere çok sayıda Bitki Koruma ürünü ruhsatlı bulanmakta olup her geçen gün yenileri eklenmektedir ( Bitki Koruma Ürünleri, http://www.bku.gov.tr). Karahan (1965) ve Aşkın (2008), Ankara' da biber ve domates fideliklerinde çökertene neden olan önemli etmenler olarak Pythium spp. ve Rhizoctonia solani' yi belirlemiştir.

Floresan Pseudomonaslar, hastalıkların baskılandığı topraklarda toprak kaynaklı hastalıkların azaltılmasında en etkili rizosfer bakterileridir. Bu bakteriler ilk kez 1980' li y1llarda gündeme gelmiştir (Kloepper and Schroth 1981b). Birçok sekonder metabolitlerinin diğer mikroorganizmaların gelişimini engellemesi, birlikte bulundukları diğer toprak bakterilerinden daha fazla mikroorganizmaları engelleyici etkiye sahip olmaları, tohum uygulaması şeklinde verilseler de rizosfer populasyonunda baskın duruma geçmeleri ve rizosferde kolonize olabilmeleri gibi özelliklere sahip olmaları patojen olmayan Pseudomonasları başarılı bir biyolojik mücadele elemanı yapmaktadır (Rovira et al. 1992, Stephens et al. 1993, Haas and Keel 2003).

Biyolojik mücadele etmeni olarak veya bitkide gelişimi teşvik ederek etkili olan florasan Pseudomonasların farklı ürünlerde (domates, pamuk, hiyar, tatlı misır, bezelye, soya fasulyesi vb.) çökertene neden olan fungal etmenlere karşı etkinlikleri değişik çalışmalarla ortaya konulmuştur (Van Wees et al. 1997, Ramamoorthy et al. 2001a, Soylu et al. 2005). 
Rizosfer bakterileri ile bitki patojenlerinin biyolojik mücadelesi üzerine yapılan çalışmalarda bakteriler değişik şekillerde uygulanabilmektedirler. Bu yöntemler; bakteri süspansiyonunun steril toprağa karıştırılması, şaşırtma esnasında fide köklerinin bakteri süspansiyonuna daldırılması veya ekimden önce yüksek sayıdaki bakteri ile tohumların kaplanmasıdır (Kluepfel 1993). Bu konuda değişik araştırıcıların farklı bulguları olmuştur.

Kimi çalışmada tohum uygulaması hastalık gelişiminin engellenmesinde daha etkili bulunurken (Howell and Stipanovic 1980, Clemente et al. 2000b, Shah-Smith and Burns 1996) kiminde toprak uygulaması hastalık çıkışının baskılanmasında daha iyi sonuçlar vermiştir (Ellis et al. 1999, Howell and Stipanovic 1980, Hendrix and Campbell 1983, Ibrahim and Mihanna 2002).

$\mathrm{Bu}$ çalışma daha önceden yapılan in vivo çalışmalar sonucunda domateste çökerten etmeni Rhizoctonia solani ve Pythium ultimum'a karşı etkili bulunan (Aşkın, 2008) antagonist floresan Pseudomonas putida fp10 bakteri izolatının hastalık etmenleri tarafından neden olunan hastalık çıkışının yanısıra bitki gelişimi üzerine farklı bakteri konsantrasyonlarında ve uygulama şekillerinde etkilerini araştırmak amacıyla yürütülmüştür.

\section{Materyal ve yöntem}

\section{Bitki materyali, Hastalık etmenleri ve Antagonist bakteri izolatı}

Çalışmalarda Ankara İlinde en fazla ekimi yapılan ve hastalık çıkışı gözlenen 73-14 (sırık domates) ve Joker (yer domatesi) çeşitleri kullanılmışır. Antagonist biyokontrol bakteri etmeni olarak Ankara İlinin Ayaş, Beypazarı ve Nallihan ilçelerinde domates yetiştiriciliği yapılan tarlalardaki sağl1lı domates bitkisinin rizosferinden izole edilmiş, tütünde HR testi yapılarak patojen olmadığı belirlenmiş, domateste çökerten hastalığına sebep olan Rhizoctonia solani ve Pythium deliense ye karşı etkili olduğu tespit edilmiş Pseudomonas putida fp10 izolatı (Aşkın, 2008) kullanılmıştır. P. putida fp10 izolatının moleküler tanılaması 16rRNA primeri kullanlarak yapılmış olup, NCBI veri tabanında yapılan araştırma sonucunda kullanılan izolatımızın \%100 benzerlikte $P$. putida olarak belirlenmiştir. Domates fide çökerten hastalık etmenleri olarak da aynı bölgedeki hasta domates fidelerinden izole edilmiş, en yüksek patojeniteye sahip $R$. solani ve $P$. deliense fungal hastalık etmenleri kullanılmıştır.

Saksı denemelerinde kullanılan topraklar 1:1:1 oranında bahçe toprağı:dere kumu:yanmış ahır gübresi karışımı şeklinde hazırlanarak toprak sterilizatöründe 121 ${ }^{\circ} \mathrm{C}^{\prime}$ de 75 dak. iki gün ard arda steril hale getirilmiştir.

Etkinlik testlerinde fungal inokulum hazırlamak amacıyla mısır unu-kum ortamı kullanılmıştır. $\mathrm{Bu}$ amaçla \%3 mısır unu- \%97 kum karışımına $20 \mathrm{kısım}$ su ilave edilerek hazırlanan ortam cam şişelere doldurmuş ve birbirini takip eden 2 gün ard arda steril hale getirilmiştir. 
$\underline{\text { Domateste Cökerten Hastalığının Biyolojik Mücadelesinde Farklı İnokulasyon Yöntemleri }}$

Fungal inokulumu hazırlamak amacıyla Yeast Dekstroz Agar (YDA) üzerinde geliştirilmiş 3-4 günlük $R$. solani ve Corn meal agar (CMA) üzerinde geliştirilmiş 5 günlük $P$. deliense, içerisinde mısır unu-kum bulunan şişelere $10^{\text {‘ }}$ ar adet olmak üzere $5 \mathrm{~mm}$ çaplı fungus diskleri konulmuştur. $R$. solani inokulumu $24 \pm 2{ }^{\circ} \mathrm{C}$ 'de, Pythium spp. inokulumu ise $21 \pm 1^{\circ} \mathrm{C}$ 'de 2-2.5 hafta süreyle inkübe edilmişlerdir (Papavizas and Davey 1962, Hatat 1995). Daha sonra saksı toprağına $R$. solani inokulumu \% 4, Pythium deliense inokulumu ise \% 5 (ağırlı/ağırlık) oranında olacak şekilde karıştırılmıştır (Papavizas and Davey 1962, Williams and Asher 1996, Ramamoorthy et al. 2002).

\section{Antagonist Pseudomonas izolatının saksı koșullarında bitki gelişimi ve hastalık etmenlerince oluşturulan hastalık çıkısı üzerine in vivo etkileri}

$\mathrm{Bu}$ denemede antagonist bakterinin $10^{8}, 10^{9}$ ve $10^{11} \mathrm{cfu} / \mathrm{ml}$ konsantrasyonlar1 kullanılmıştır. Antagonist bakteri P. putida fp10, Joker ve 73-14 domates çeşitleri için; (i) tohuma, (ii) toprağa ve (iii) tohum + toprağa olmak üzere 3 farklı şekilde ayrı ayrı uygulanmıştır. Deneme sonunda her iki domates çeşidinde $R$. solani $+P$. deliense hastalık etmenlerince oluşturulan hastalık şiddetinin yanısıra, bakteri uygulamasının bitki gelişimi (fide boyları) üzerine olan etkinlikleri belirlenmiştir. Deneme öncesinde domates tohumlarının çimlenme oranları (\%), ISTA kurallarına göre belirlenmiştir. İçine steril kurutma kağıtları yerleştirilip nemlendirilen 4 adet petri kabına 100'er adet domates çeşidi tohumu yerleştirilmiştir. Petriler $20-30{ }^{\circ} \mathrm{C}$ ' de muhafaza edilmiş ve 5 . ve 14 . günlerde sayımlar yapılmıștır.

Domates tohumları $3 \mathrm{dk} \% 1$ lik $\mathrm{NaOCl}$ ile yüzeysel dezenfeksiyon yapılmış ve üç kez steril destile su ile yıkanarak kurutulmuştur. Mc Farland skalasına göre (Barret 1975) $10^{8}, 10^{9}$ ve $10^{11} \mathrm{cfu} / \mathrm{ml}$ ' ye ayarlanan bakteri süspansiyon konsantrasyonları $1 \mathrm{~g}$ tohuma $10 \mathrm{ml}$ gelecek şekilde hazırlanmış ve bu süspansiyonda tohumlar bir gece süreyle (12 saat) bekletilmiștir. Bakterilerin homojen dağılımını sağlamak için süspansiyona 1-2 damla Tween 80 ilave edilmiştir (Ramamoorthy et al. 2002).

Saksı denemelerinde 6 numaralı saksılar kullanılmış ve daha önce patojenlerin inokule edildiği bu saksılara 7-10 günlük gelişme periyodundan sonra 25'şer adet domates tohumu ekilmiştir. P.putida $10 \mathrm{fp}$ ayrı ayrı uygulanmıştır.

Bitkiler $24 \pm 2{ }^{\circ} \mathrm{C}$ sicaklık ve $\% 75-80$ nem, 14 saat aydınlık 10 saat karanlık periyot koşullarında yetiştirilmişlerdir. Deneme tesadüf parselleri deneme desenine göre 4 tekrarlı olarak düzenlenmiştir. Bitkiler düzenli olarak sulanmıştır. Otuz günün sonunda $R$. solani $+P$. deliense test patojenlerine karşı oluşan hastalık şiddeti 0-4 skalasına göre değerlendirilmiş (Chandler and Santelman 1968) (Çizelge 1). Uygulamaların bitki gelişimine olan etkinliğinin belirlenmesi için fide boyları ölçülmüștür.

Uygulamalar arasındaki farklılı̆̆ın ortaya konulması için SPSS istatistik programı kullanılarak varyans analizleri yapılmıştır. Skalaya göre elde edilen 
değerler Towsend -Heuberger formulüne uygulanarak hastalık şiddeti hesaplanmış, hastalık şiddeti değerlerinden Abbott formülü ile bakteri izolatlarının etkinlikleri belirlenmiştir. Hastalık şiddetlerinin açı değerleri karşılıkları alınmış. Bu değerler üzerinden yapılan Duncan testi ile hastalık şiddetleri kıyaslanmıştır.

Fide gelişimleri SPSS istatistik programı kullanılarak varyans analizine tabi tutulmuş ve izolatlar arasındaki farklılıklar Duncan Çoklu Karşılaştırma Testi ile tespit edilmiştir $(\mathrm{P} \leq 0.05)$.

Çizelge 1. Hastalık şiddeti değerlendirmesi için kullanılan 0-4 skalası

Table1. 0-4 scales used for detemination of disease severity

\begin{tabular}{|c|l|}
\hline $\begin{array}{l}\text { Skala } \\
\text { değeri }\end{array}$ & Açılama \\
\hline 0 & Fidede herhangi bir zararlanma yok \\
\hline 1 & $\begin{array}{l}\text { Fidenin toprak yüzeyi ile birleştiği yerde renk açılması } \\
\text { ve küçük lezyonlar }\end{array}$ \\
\hline 2 & Daha büyük lezyonlar gövdeyi çevirmiş durumda \\
\hline 3 & $\begin{array}{l}\text { Gövdeyi çevreleyen büyük lezyonlar, sonuçta konkav bir } \\
\text { görünüm }\end{array}$ \\
\hline 4 & Organizma zararı sonucu ölü bitki \\
\hline
\end{tabular}

\section{Bulgular ve tartışma}

Deneme sonunda P.putida fp10 nolu antagonist adayı bakteri izolatının 73-14 domates çeşidinde tohuma, toprağa, ya da tohum+toprağa şeklindeki uygulamalar ile farklı bakteri konsantrasyonları $\left(10^{8}, 10^{9}\right.$ ve $\left.10^{11} \mathrm{cfu} / \mathrm{ml}\right)$ arasında bir fark olmadığı görülmüştür (Çizelge 2, Şekil 1). Farklı uygulamaların hastalık çıkışı üzerine olan etkinliğin belirlendiği çalışmalar sonucunda, Tohum+toprak uygulamasinda $\% 55.04$, toprak uygulamasinda $\% 50.18$, tohum uygulamasinda ise $\% 46.90$ oranlarda hastalık çıkışını engellediği belirlenmiştir.

Çizelge 2. P. deliense $+R$. solani uygulamasından sonra $P$. putida fp10 nolu bakterinin farklı uygulama şekli ve dozlarında 73-14 domates çeşidinde ortaya çıkan ortalama hastalık oranı ve etki değerleri

Table 2. Average disease severity and efficacy values in different application shapes and doses of $P$. putida fp10 after $P$. deliense $+R$. solani application in 73-14 tomato variety

\begin{tabular}{|l|lc|l|l|lc|}
\hline $\begin{array}{l}\text { Uygulama } \\
\text { şekli }\end{array}$ & $\begin{array}{l}\text { Ortalama } \\
\text { Hastalik Oranı } \\
(\%)^{*}\end{array}$ & $\%$ Etki & $\begin{array}{l}\text { Uygulama } \\
\text { dozu }\end{array}$ & $\begin{array}{l}\text { Ortalama Hastalik } \\
\text { Oran1 }\end{array}$ \\
\hline Tohum+toprak & $30.64 \pm 2.33$ a & 55.04 & $10^{9}$ & $39.58 \pm 5.09$ & a \\
\hline Toprak & $33.95 \pm 2.61$ & $\mathrm{a}$ & 50.18 & $10^{8}$ & $43.03 \pm 4.47$ & $\mathrm{a}$ \\
\hline Tohum & $36.19 \pm 4.30$ & $\mathrm{a}$ & 46.90 & $10^{11}$ & $44.08 \pm 4.48$ & $\mathrm{a}$ \\
\hline Kontrol & $68.15 \pm 2.77$ & $\mathrm{~b}$ & & & & \\
\hline
\end{tabular}


$\underline{\text { Domateste Cëkerten Hastalığının Biyolojik Mücadelesinde Farklı İnokulasyon Yöntemleri }}$

* Dört tekerrür ortalamasıdır. Aynı harfle ifade edilen değerler arasında fark yoktur. $\mathrm{P} \leq 0.05$

Bakteri uygulama şekli ve konsantrasyonların bitki gelişimi üzerine olan etkinliklerin belirlendiği çalışmalarda, uygulama şekli yönünden değerlendirildiğinde, tohum ve tohum + toprağa yapılan uygulamalarda fide boyunun bütün yoğunluklarda aynı olduğu, toprak uygulamasında en iyi etkiyi $10^{8}$ yoğunluğun $(22.45 \mathrm{~cm}$ ) sağladığı belirlenmiştir (F: 4.040, P: 0.003). Uygulama dozu bakımından ise $10^{8}$ en yüksek etkiyi toprak uygulamasında, $10^{9}$ tohum+toprak uygulamasında, $10^{11}$ ise bütün uygulamalarda aynı etkiyi göstermiștir (Çizelge 3 , Şekil 1).

Çizelge 3 P. deliense $+R$. solani uygulamasından sonra $P$. putida fp10 nolu bakterinin farklı uygulama şekli ve dozlarının 73-14 domates çeşidinde fide gelişimine (cm) etkileri * Table 3. Effects of different application shapes and doses of seedlings (cm) on 73-14 tomato variety of tomato seedlings of $P$. putida fp10 after $P$. deliense $+R$. solani application *

\begin{tabular}{|c|c|c|c|}
\hline \multirow{2}{*}{$\begin{array}{l}\text { Uygulama } \\
\text { şekli }\end{array}$} & \multicolumn{3}{|l|}{ Uygulama dozu } \\
\hline & $10^{8}$ & $10^{9}$ & $10^{11}$ \\
\hline Tohum & $13.45^{*} \pm 0.84 \mathrm{a}^{* * *} \mathrm{~B}^{* *}$ & $16.45 \pm 2.00 \quad \mathrm{a} \mathrm{AB}$ & $15.55 \pm 0.36$ a $\quad \mathrm{A}$ \\
\hline Toprak & $22.45 \pm 1.36 \mathrm{a} \quad \mathrm{A}$ & $17.85 \pm 1.42 \quad \mathrm{~b} \mathrm{AB}$ & $15.25 \pm 0.96 \quad$ b $\quad$ A \\
\hline $\begin{array}{l}\text { Tohum+ } \\
\text { toprak }\end{array}$ & $16.38 \pm 0.63 \mathrm{a} \quad \mathrm{B}$ & $19.55 \pm 1.33$ a $\mathrm{A}$ & $17.30 \pm 1.15$ a $\mathrm{A}$ \\
\hline Kontrol & $15.45 \pm 0.99$ & $15.45 \pm 0.99$ & $15.45 \pm 0.99$ \\
\hline
\end{tabular}

* 5 adet domates fidesine ait ortalama

** Aynı sütundaki farklı büyük harf taşıyan değerler istatistiksel olarak birbirinden farklı olup uygulama dozlarını değerlendirmektedir.

*** Aynı satırdaki farklı küçük harf taşıyan değerler istatistiksel olarak birbirinden farklı olup uygulama şeklini değerlendirmektedir.

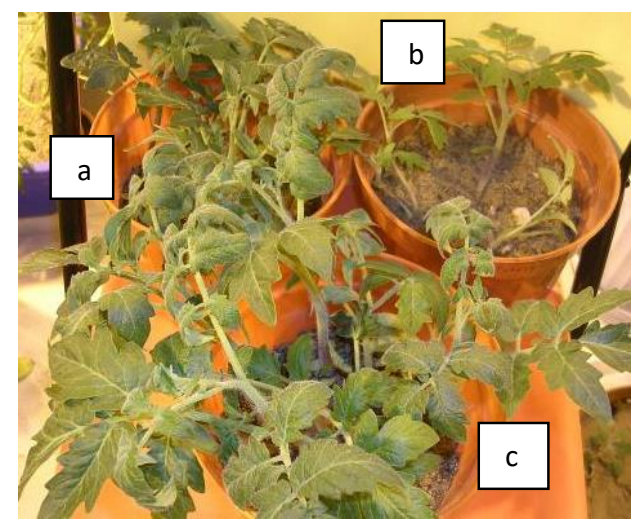

Şekil 1 Toprağa $10^{8} \mathrm{cfu} / \mathrm{ml}$ konsantrasyonunda bakteri uygulaması yapılmış 73-14 çeşidi domates bitkisi. a. Sağlıklı bitki, b. Hasta bitki, c. Bakteri izolatı uygulanmış bitki

Fig. 1 Bacteria treated to soil at the concentration of $10^{8} \mathrm{cfu} / \mathrm{ml}$ in $73-14$ variety tomato a. Healthy plant, b. disease plant, c. Bacteria applied plant 
Joker domates çeşidinde bakterinin tohuma, toprağa ya da tohum + toprağa uygulanması ve farklı uygulama yoğunlukları $\left(10^{8,} 10^{9}\right.$ ve $\left.10^{11} \mathrm{cfu} / \mathrm{ml}\right)$ arasında önemli bir fark olmamıştır (Çizelge 4, Şekil 2). Tohum+toprak uygulamasında etki $\% 61.18$, toprak uygulamasinda $\% 60.49$, tohum uygulamasinda ise $\% 56.77$ olmuştur

Çizelge 4 P. deliense $+R$. solani uygulamasından sonra $P$. putida fp 10 nolu bakterinin farklı uygulama şekli ve dozlarında joker domates çeşidinde ortaya çıkan ortalama hastalık oranı ve etki $(\%)$

Table 4. Average disease severity and efficacy values in different application shapes and doses of $P$. putida $\mathrm{fp} 10$ after $P$. deliense $+R$. solani application in joker tomato variety

\begin{tabular}{|l|ll|l|l|lll|}
\hline $\begin{array}{l}\text { Uygulama } \\
\text { şekli }\end{array}$ & $\begin{array}{l}\text { Ortalama Hastalık } \\
\text { Oranı (\%)* }\end{array}$ & $\%$ Etki & $\begin{array}{l}\text { Uygulama } \\
\text { dozu }\end{array}$ & $\begin{array}{l}\text { Ortalama } \\
\text { Oran } 1\end{array}$ & Hastalık \\
\hline Tohum+toprak & $23.78 \pm 1.65$ & $\mathrm{a}$ & 61.18 & $10^{9}$ & $32.74 \pm 4.52$ & $\mathrm{a}$ \\
\hline Toprak & $24.20 \pm 1.95$ & $\mathrm{a}$ & 60.49 & $10^{8}$ & $33.69 \pm 4.40$ & $\mathrm{a}$ \\
\hline Tohum & $26.48 \pm 2.10$ & $\mathrm{a}$ & 56.77 & $10^{11}$ & $35.36 \pm 4.39$ & $\mathrm{a}$ \\
\hline Kontrol & $61.25 \pm 2.43$ & $\mathrm{~b}$ & & & & & \\
\hline
\end{tabular}

* Dört tekerrür ortalamasıdır. Aynı harfle ifade edilen değerler arasında fark yoktur. $\mathrm{P} \leq 0.05$

Farklı uygulama şekli ve dozları fide boylarını farklı şekillerde etkilemişlerdir (F: 2,853; P: 0,022). Uygulama şekli yönünden değerlendirildiğinde, $10^{9}$ ve $10^{11}$ dozlarında tohum ve $10^{8}$ dozunda toprak (21.48) ve tohum+toprak (21.10) uygulamaları en yüksek fide boyu değerini vermiştir. Uygulama dozları bakımından değerlendirildiğinde ise, $10^{8}$ toprak ve toprak+tohum uygulamasında etkili olurken, $10^{9} \mathrm{ve} 10^{11} \mathrm{cfu} / \mathrm{ml}$ uygulamaları aynı etkiyi göstermiştir (Çizelge 5, Şekil 2).

Çizelge 5 P. deliense $+R$. solani uygulamasından sonra $P$. putida fp 10 nolu bakterinin farkl 1 uygulama şekli ve dozlarının joker domates çeşidinde fide gelişimine $(\mathrm{cm})$ etkileri *

Table 5. Effects of different application shapes and doses of seedlings $(\mathrm{cm})$ on joker tomato variety of tomato seedlings of $P$. putida $\mathrm{fp} 10$ after $P$. deliense $+R$. solani application *

\begin{tabular}{|c|c|c|c|}
\hline \multirow{2}{*}{$\begin{array}{l}\text { Uygulama } \\
\text { şekli }\end{array}$} & \multicolumn{3}{|l|}{ Uygulama dozu } \\
\hline & $10^{8}$ & $10^{9}$ & $10^{11}$ \\
\hline Tohum & $13.13^{*} \pm 1.00 \mathrm{~b}^{* * *} \mathrm{~B}^{* *}$ & $17.73 \pm 2.47 \quad$ a A & $16.65 \pm 1.77 \quad$ a $\quad \mathrm{A}$ \\
\hline Toprak & $21.48 \pm 0.82$ a A & $17.42 \pm 1.93$ b A & $17.90 \pm 1.49$ ab A \\
\hline $\begin{array}{l}\text { Tohum+ } \\
\text { toprak }\end{array}$ & $21.10 \pm 0.81 \mathrm{a} \quad \mathrm{A}$ & $17.00 \pm 0.14 \quad$ b A & $18.73 \pm 1.18 \quad a b A$ \\
\hline Kontrol & $15.53 \pm 0.56$ & $15.53 \pm 0.56 \quad \mathrm{~A}$ & $15.53 \pm 0.56$ \\
\hline
\end{tabular}

$* 5$ adet domates fidesine ait ortalama

** Aynı sütundaki farklı büyük harf taşıyan değerler istatistiksel olarak birbirinden farklı olup uygulama dozlarını değerlendirmektedir.

*** Aynı satırdaki farklı küçük harf taşıyan değerler istatistiksel olarak birbirinden farklı olup uygulama şeklini değerlendirmektedir. 


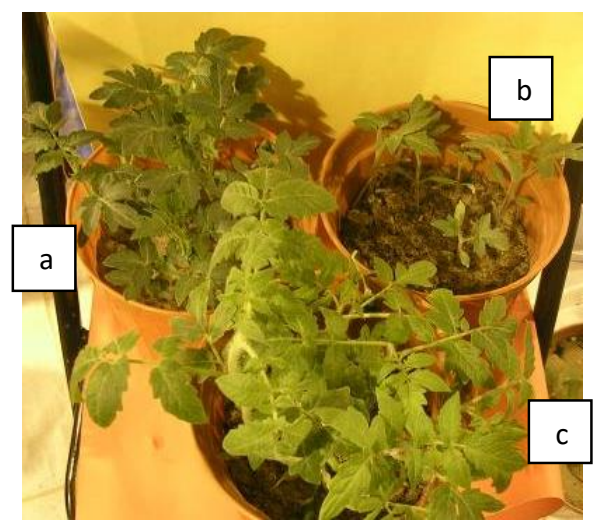

Şekil 2 Tohum + toprağa $10^{8} \mathrm{cfu} / \mathrm{ml}$ konsantrasyonunda bakteri uygulaması yapılmış joker çeşidi domates bitkisi a. Sağlıklı bitki, b. Hasta bitki, c. Bakteri izolatı uygulanmış bitki Fig. 2 Bacteria treated to soil at the concentration of $10^{8} \mathrm{cfu} / \mathrm{ml}$ in joker variety tomato a. Healthy plant, b. disease plant, c. Bacteria applied plant

P.putida fp10' un tohuma uygulamasında tohum bakterizasyonu için 12 saatlik bir inkübasyon periyodu kullanılmıştır. Tohuma yapılan bakteri uygulamalarında iyi bir tohum bakterizasyonu, sonucu olumlu yönde etkilemektedir. Clemente et al. (2000b), domateste çökerten etmeni $R$. solani' nin kontrolünde floresan Pseudomonasların 2 saat süreli tohum bakterizasyonu ile kıyaslandığında 12 saatlik tohum bakterizasyonunun tohum içine giren bakteri sayısını artırdığını tespit etmişlerdir. $1 \times 10^{9} \mathrm{cfu} / \mathrm{ml}$ içeren P. fluorescens P190, her tohumda ortalama $5.55 \times 10^{5}$ olarak ölçülmüştür. En yüksek koruma 12 saat süreyle yapılan tohum bakterizasyonunda olmuştur. 2 saat tohum bakterizasyonunda koruma \% 19 iken 12 saatte bu oran $\% 31$ olmuştur.

Yapılan çalışmalarda Laboratuar ve sera testleri bazı rizosfer bakterilerinin tohum, yumru ya da toprağa uygulandığında bitki gelişimini artırdığını göstermiştir. (Kloepper and Schroth 1981a). Bizim çalışmamızda bakterinin tohum, toprak ya da tohum+toprak şeklinde uygulanması her iki domates çeşidinde de fide gelişimini olumlu etkilerken en iyi fide gelişimi $10^{8} \mathrm{cfu} / \mathrm{ml}$ konsantrasyonunda bakterilerin toprağa yapılan uygulamasında görülmüştür. Yürüttüğümüz araştırma sonunda uygulama şekillerinin (tohum, toprak, tohum+toprak) çökertene karşı oluşan hastalığ korumada en yüksek etki her iki çeşitte de tohum+toprak uygulamasında daha sonra ise toprak ve tohum uygulamasında görülmekle beraber her üç uygulamadaki hastalık şiddetleri arasındaki fark istatistiki olarak önemsiz bulunmuştur.

Bu konuda değişik araştırıcılara ait farklı bulgular bulunmaktadır. P. fluorescens pf5 tarafından üretilen pyoluteorin tohum kaplaması şeklinde uygulandığında pamuk fidelerinde çökertene neden olan P. ultimum' u engellemede başarılı olurken toprağa verildiğinde etkili olamamıştır. Bunun nedeni bakteri tarafından oluşturulan antifungal maddelerin toprak kolloidleri tarafından etkisiz kılınmasına bağlanmıştır 
(Howell and Stipanovic 1980). Yine, Clemente et al. (2000b), yürüttükleri araştırmada tohum bakterizasyonunun domateste çökertene neden olan $R$. solani' yi engellemede etkili sonuç verirken fide çıkışında ya da 7 gün sonra sulama suyu şeklinde verilen bakterizasyonun korumadaki başarıyı engellediğini tespit etmişlerdir. Diğer taraftan, Yoem et al. (1995), hiyarlarda çökertene neden olan $R$. solani ve $P$. ultimum' un azalmasinda $P$. fluorescens $\mathrm{M} 45$ ' in tohum uygulamasi ve MC07' nin toprak uygulamasının oldukça etkili olduğunu tespit etmişlerdir. Her iki bakteri izolatının kombinasyonu tek tek uygulanmalarından daha başarılı sonuç vermiştir. Bir başka çalışmada şekerpancarından izole edilen P. fluorescens 54/96 bezelyede çökertene neden olan $P$. ultimum' a karşı toprağa sulama suyu şeklinde verildiğinde tohum kaplamasına göre daha etkili olmuştur (Ellis et al. 1999). Pythium hifleri tohuma doğru hızla çimlendiklerinden (Hendrix and Campbell 1983) bakteri, patojenin oospor çimlenmesini engelleyerek hastalığ patojene karş1 etkili bir kontrolde $10^{3} \mathrm{cfu} / \mathrm{ml} P$. fluorescens $54 / 96$ populasyonu yeterli olmuştur. 7 gün sonra topraktaki bu yoğunluk $10^{6} \mathrm{cfu} / \mathrm{ml}$ 'ye ulaşmıştır. Ibrahim and Mihanna (2002), patlicanda çökertene neden olan $R$. solani' ye karşı 103, 106 ve 115 nolu Pseudomonas izolatlarının toprağa yapılan uygulamalarının tohum kaplaması uygulamalarından daha etkili olduğunu bildirmişlerdir. Sonuçların farklı çökerten etmenleri ve farklı etki mekanizmalarına göre değiştiği görülmektedir.

Deneme sonunda bakteri uygulama konsantrasyonları $\left(10^{8}, 10^{9}, 10^{11} \mathrm{cfu} / \mathrm{ml}\right)$ arasında her iki çeşitte en düşük hastalık oran $10^{9}$ uygulamasında, daha sonra ise $10^{8}$ ve $10^{11} \mathrm{cfu} / \mathrm{ml}$ uygulamasında görülmekle beraber her üç uygulamadaki hastalık şiddetleri arasındaki fark istatistiki olarak önemsiz bulunmuştur. Raaijmakers and Weller (1998), eşik yoğunluğu üzerindeki yoğunluklarda patojen olmayan Pseudomonas spp.' nin hastalıkları baskılama düzeyinde önemli bir artışa neden olmadığını bildirmiştir. Bizim çalışmamızda da bakteri izolatının patojenlere karşı gösterdiği korumada, farklı uygulama dozları arasında önemli bir fark olmamıştır. $\mathrm{Bu}$ sonuç diğer araştırmacıların Shah-Smith and Burns (1996), Raaijmakers and Weller (2001), Schmidt et al. (2004) bulgulariyla paralellik göstermiştir.

Sonuç olarak domateste çökerten etmeni patojenler $P$. deliense ve $R$. solani' ye karşı her iki çeşit içinde P.putida fp10' un $10^{8} \mathrm{cfu} / \mathrm{ml}$ dozunda toprak uygulamasının hem hastalığı önlemede hem de fide gelişiminde tercih edilebileceği söylenebilir.

\section{Kaynaklar}

Aşkın A. ve Katırcıoğlu Y.Z., 2008. Ankara İli Ayaş, Beypazarı ve Nallıhan İlçelerinde Domates Fideliklerindeki Çökerten etmenlerinin Tespiti ve Patojenisite Durumları. Bitki Koruma Bülteni. Bitki Koruma Bülteni, 48.

Bitki Koruma Ürünleri, http://www.bku.gov.tr. Erișim Tarihi. 20.09.2017

Barret, T. 1975. Preparation of bacterial vaccine. In Proceeding of the first work shop of phytobacteriology. R. N. Goodman (ed.). Columbia. University of Missouri, p. 1-6. 
$\underline{\text { Domateste Cëkerten Hastalığının Biyolojik Mücadelesinde Farklı İnokulasyon Yöntemleri }}$

Chandler, J.M and Santelman, P.W. 1968. Interaction of four herbicides with Rhizoctonia solani on seedling cotton. Weed Science, (16); 453-454.

Clemente, G., Quadrelli, A.M., Melegari, A. and Escande, A. 2000b. Inoculation methods of fluorescent Pseudomonas to control tomato damping off (Rhizoctonia solani AG-4). Fifth International PGPR Workshop. Organizator: APS, Argentina. http://www.inta.gov.ar/balcarce/info/documentos/posters/ant22/AliciaMeleg.htm. Erişim tarihi:2008

Ellis, R.J., Timms Wilson, T.M., Beringer, J.E., Rhodes, D. Renwick, A., Stevenson, L and Bailey, M. J. 1999. Ecological basis for biocontrol of damping-off disease by Pseudomonas fluorescens 54/96. Journal of Applied Microbiology, 87, 454-463.

Haas, D and Keel, C. 2003. Regulation of antibiotic production in root colonizing Pseudomonas spp. and relevance for biological control of plant diseases. Annual Review of Phytopathology, 41, 1117-1153.

Hendrix, J. and Campbell, W. A. 1983. Some phytiaceous fungi. In Zoosporic Plant Pathogens (ed. BUczacki, S.t.), pp. 123-160. London Academin pres.

Howell, C. R. and Stiponavic, R. D. 1980. Suspension of Pythium ultimum induced dampingoff of cotton seedlings by Pseudomonas fluorescens and its antibiotics, pyoluteorin. Phytopathology, 70 (8); 712-715.

İbrahim, G. H. and Al- Mihanna, A. A. 2002. The use of some plant oils and antagonistic bacteria to reduce the incidence of damping off caused by Rhizoctonia solani in eggplant. Arab- Universities Journal of Agricultural Sciences, 10 (1); 351-361.

Karahan, O. 1965. Muhtelif Sebzelerde Zararlı Hastalık Amilleri ve Mücadele T.B.A.Z.M. E.Müdürlüğü Sayı:42.

Kloepper, J. W. and Schroth, M. N. 1981a. Plant-growth promoting rhizobacteria and plant growth under sinotobiotic conditions. Phytopathology. 71, 642-644.

Kloepper, J. W. and Schroth, M. N. 1981b. Relationship of in vitro antibiosis of plant growth promoting rhizobacteria to plant growth and the displacement of root microflora. Phytopathology, 72, 33-36.

Kluepfel, D. A. 1993. The behavior and tracking of bacteria in the rhizosphere. Annu. Rev. Phytopath, 31, 441-72.

Papavizas, G. C. and Davey, C. B. 1962. Activity of Rhizoctonia in soil as affected by carbon dioxide. Phytopathology, 52, 759-766.

Raaijmakers, J. M. and Weller, D.M. 1998. Natural plant protection by 2,4-Diacetylphloriglucinol-producing Pseudomonas spp in take-all decline soils. Mol. PlantMicrobe Interact, 11, 144-152.

Raaijmakers, J., M. and Weller, D., M. 2001. Exploting genotypic diversity of 2,4Diacetyl-phloriglucinol- producing Pseudomonas spp.: characterization of superior root-colonizing $P$. fluorescens strain Q8r1-96. Applied and Environmental Microbiology, pp. 2545-2554.

Ramamoorthy, V., Raguchander, T. and Samiyappan, R. 2002. Enhancing resisitance of tomato and hot pepper to Pythium diseases by seed treatment with fluorescent Pseudomonas. European Journal of Plant Pathology, 108, 429-441.

Rovira, A., Ryder, M. and Haris, A. 1992. Biological control of root diseases with pseudomonas, 175-183, Tjamas, E. S. Et al. (Eds), Plenum pres, New York.

Schmidt, C. S., Agostini, F., Leifent, G., Killham, K. and Mullins, C. E. 2004. Influence of inoculum density of the antagonistic bacteria Pseudomonas fluorescens and 
Pseudomonas corrugata on sugar beet seedling colonisation and suppression of Pythium damping off. Plant and Soil, 265 (1-2); 111-122.

Shah-Smith D. A. and Burns, R. G. 1996. Biological control of damping-off of sugar beet by Pseudomonas putida applied to seed pellets. Plant Pathology, 45, 572-582.

Soylu, S., Soylu, E.M., Kurt, Ş. and Ekici, Ö.K. 2005. Antagonistic potentials of rhizosphereassociated bacterial isolates against soil-borne diseases of tomato and pepper caused by Sclerotinia sclerotiorum and Rhizoctonia solani. Pakistan Journal of Biological Sciences 8, 43-48.

Stephens, C. T., Herr, L. J., Schmitthenner, A. F., and Powell, C. C. 1982.Characterization of Rhizoctonia isolates associated with damping-off of bedding plants. Plant Dis. 66:700-703

Stephens, C. T., and Powell, C. C. 1982. Pythium species causing damping-off of seedling bedding plants in Ohio greenhouses. Plant Dis. 66:731-733.

Stephens, P. M., Crowley, J. J. and O' Connell, C. 1993. Selection of Pseudomonads strains inhibiting Pythium ultimum on sugarbeet seeds in soil. Soil Biology and Biochemistry, 25, 1283-1288.

Walker, J. C. 1952.Diseases of vegetable crops. McGraw-Hill Book Campany. Inc. New York, $529 \mathrm{pp}$.

Williams, G. E. and Asher, M. J. C. 1996. Selection of rhizobacteriafor the control of Pythium ultimum and Aphanomyces cochlioides on sugar-beet seedlings. Crop Protection, 15(5); 479-486. 